\title{
Article \\ The Effects of Wind-Driven Storm Events on Partly Sheltered Estuarine Beaches in Batemans Bay, New South Wales, Australia
}

\author{
Alexander Wang ${ }^{1,2, *}$, Xiao Hua Wang ${ }^{3}$ and Gang Yang ${ }^{3}$ \\ 1 Canberra Grammar School, Canberra, ACT 2603, Australia \\ 2 School of Law, University of Sydney, Sydney, NSW 2006, Australia \\ 3 The Sino-Australian Research Consortium for Coastal Management, School of Science, \\ The University of New South Wales, Canberra, ACT 2600, Australia; x.h.wang@unsw.edu.au (X.H.W.); \\ g.yang@student.unsw.edu.au (G.Y.) \\ * Correspondence: yu677blue@gmail.com
}

check for updates

Citation: Wang, A.; Wang, X.H.; Yang, G. The Effects of Wind-Driven Storm Events on Partly Sheltered Estuarine Beaches in Batemans Bay, New South Wales, Australia. J. Mar. Sci. Eng. 2021, 9, 314. https:// doi.org/10.3390/jmse9030314

Academic Editor: Riccardo Brigant

Received: 30 January 2021

Accepted: 6 March 2021

Published: 12 March 2021

Publisher's Note: MDPI stays neutral with regard to jurisdictional claims in published maps and institutional affiliations.

Copyright: (c) 2021 by the authors. Licensee MDPI, Basel, Switzerland. This article is an open access article distributed under the terms and conditions of the Creative Commons Attribution (CC BY) license (https:/ / creativecommons.org/licenses/by/ $4.0 /)$.

\begin{abstract}
Extreme wind-driven storm events have the potential to erode beach systems. Along the East Coast of Australia, storm events have been responsible for beach erosion in many coast-facing, open beaches. This paper investigates the potential impacts of wind-driven storms on partly sheltered estuarine beaches-a niche found within Batemans Bay, New South Wales (NSW), along the East Coast. It combines beach geomorphological data with meteorological and oceanographic data to evaluate the impacts of large storm events on three partly sheltered estuarine embayed beaches (Cullendulla Beach, Corrigans Beach, and Maloney's Beach). The results show that while embayed beaches are protected from some storm events, storm impacts may vary with the season due to wind speed and direction changes, the presence of nearby rivers or creeks, and anthropogenic modifications such as dredging and coastline alterations. This study may contribute to the understanding of the erosive impacts of storms and help improve management strategies used to prevent recession, particularly on embayed beaches.
\end{abstract}

Keywords: Batemans Bay; embayed beach; coastal erosion; beach recession; storm events; wind waves; estuary

\section{Introduction}

The stability of our coastal environments has been put in jeopardy by greater numbers of climate change-related extreme weather events and increasing human activity. "Coasts are one of the most dynamic and fragile environments on earth" [1], and now more than ever, coastal environments are being actively eroded, resulting in damage to coastal infrastructure. The East Coast of Australia is a prime example of this growing erosional threat. Spring tides, storm surges, and major wind-driven storms due to low pressure systems (dubbed "East Coast Lows" or ECL) have caused catastrophic damage to both private and public infrastructure. An ECL event in 2016 resulted in the collapse of several houses in Sydney and an emergency evacuation of residents in the suburb of Collaroy [2]. As a result, local governments have further emphasized building regulations first established in the 1990s [3] which require developers to build further from the foredune. Many insurers now choose to refuse to insure beach houses most at risk [4].

Most of these severe beach erosion events occur on open, coast-facing beaches, such as the previously mentioned Collaroy Beach, and exposed estuarine beaches, such as Jimmys Beach and Mackeral Beach in New South Wales (NSW), Australia. Loureiro et al. (2014) [5] investigated the beach response to extreme storm events in eastern South Africa, southwestern Portugal, and north-western Ireland. They demonstrated that storm-induced morphological change is highly variable among those beaches. The morphological impacts and effects along the coast of Rio de Janeiro, Brazil, were found to be sensitive to fetch limited conditions and beach directions [6]. Harley et al. (2017) [7] studied the spatial 
variability in the morphological response along the southeast Australia coastline. They primarily attributed the beach erosion observed during an ECL to its anomalous wave direction. According to Hennecke (2004) [8] and Kinsela et al. (2017) [9], the severity of coastal erosion along the coastline of this temperate region is expected to increase with the future climate, as the accelerating global mean sea-level rise begins to enhance or dominate local shoreline dynamics. However, the potential impacts for closed or embayed beaches - beaches with "one or two natural or artificial impermeable boundaries" [10] —are still relatively unknown. Vila-Concejo et al. (2018) [11] defined these beaches as bay and estuary beaches (BEBs). They demonstrated that the morphodynamics of BEBs may be controlled by oceanographic forcings, such as ocean waves, fluvial currents, and tides. The shape and size of the ocean entrance can affect these forcings and thus also affect the sediment dynamics of BEBs. Moreover, coastline changes in tidal inlets and on estuarine beaches can also be induced by anthropogenic activities, such as river channel dredging and seawall constructions [12,13].

One such coastal area in Australia with many BEBs is Batemans Bay, NSW, which is a popular beach destination for residents of Australia's inland city capital, Canberra, along the East Coast. Burston (2006) [14] used a stochastic model to simulate the extreme coastal sea level induced by storm surges, wave set-up, and tides along the NSW coast, including Batemans Bay. The aim of their study was to describe extreme wave climate and storm occurrence for sites along the NSW coast. Outside of scoping studies and reports for the local council, the long-term and short-term impacts of wind-driven storms on Batemans' beaches have not been explored. Given the potential for an increasing recurrence of storm events along the East Coast in future climate change scenarios, the stability and health of beaches in Batemans Bay may also be at risk. Determining the presence of storm erosion outside of open beaches may also help define the overall impact of climatic events and create a more reasonable prediction of future erosion if extreme climatic events increase in frequency.

This paper combines beach geomorphological data with meteorological data and wave modeling to evaluate the impacts of large storm events on three embayed beaches, namely, Cullendulla Beach, Corrigans Beach, and Maloney's Beach in Batemans Bay, New South Wales, Australia. In particular, field surveys of beach profiles were conducted on these three beaches to measure the beach morphodynamic response to ECL events. Seventysix-years of intermittent historical beach data from photogrammetry were also analysed to investigate the seasonal and interannual variability, in combination with wind data and SWAN (Simulating Waves Nearshore) wave modeling under idealized seasonal wind conditions.

\section{Study Site}

\subsection{Batemans Bay}

Batemans Bay is a town in the south east of Australia in New South Wales (35.7144 $\mathrm{S}$, $150.1795^{\circ}$ E). The town resides upon the confluence between the Clyde River and the South Pacific Ocean (Figure 1). The bay is distinctly "funnel-shaped", with the Tollgate Islands at the mouth of the bay giving some protection to many of the beaches within. Batemans Bay is approximately $151 \mathrm{~km}$ from Canberra, Australian Capital Territory, and had a population of 11,294 [15] in 2016. The bay has a total area of $28 \mathrm{~km}^{2}$ and has an average depth of $11.1 \mathrm{~m}$. Batemans Bay has a tidal range of $1.85 \mathrm{~m}$ [16]. Though funnel-shaped coasts are generally tide-dominated, Batemans Bay also displays wave-dominated coastal features, with both erosional and depositional features along the coastline and significant wave-driven longshore drift along several beaches [17]. Geologically, the embayment is most likely to have evolved in a similar fashion to other drowned river valleys on this coast. These deeply incised valleys were partially filled by marine sediment following the culmination of the most recent postglacial marine transgression (c. 7500calBP, Switzer et al., 2010) [18]. 


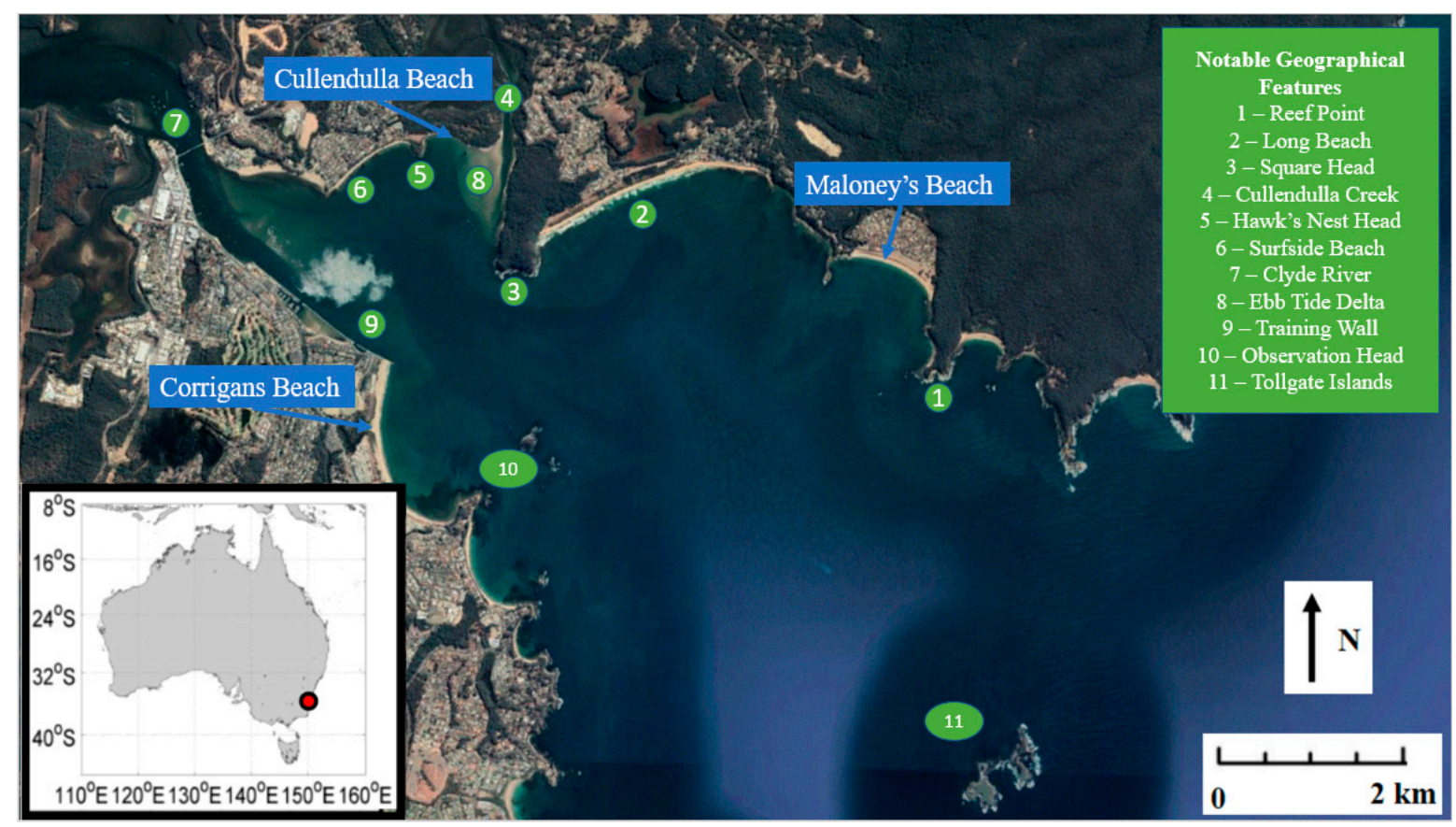

Figure 1. Satellite map of Batemans Bay $\left(35.7144^{\circ} \mathrm{S}, 150.1795^{\circ} \mathrm{E}\right)$ with spot markers for site locations and notable geographical features. The inset is a map of Australia with the location of Batemans Bay marked with a red dot (source: Google Earth 2020).

\subsection{Beaches}

Maloney's Beach, Corrigans Beach, and Cullendulla Beach (Figure 1) were chosen as research sites to create a systematic sample of embayed beaches across Batemans Bay. All three have one or more ocean facing headlands that reduce wave impacts on the beach. The sediment grain size of the three beaches is similar, ranging from fine to medium sand $(0.125 \mathrm{~mm}<\mathrm{d}<0.5 \mathrm{~mm})$.

\subsubsection{Maloney's Beach}

Maloney's Beach is on the northern side of Batemans Bay. It is $28 \mathrm{~m}$ wide and $810 \mathrm{~m}$ long and faces a $200^{\circ}$ angle with a dune height of $3.5 \mathrm{~m}$. Maloney's Beach is exposed to waves with a lower energy because it is embayed by Reef Point, which is a headland at the eastern end of the beach. Due to the beach's shape, waves are refracted toward the west. However, the beach is a stable sediment compartment and has reached equilibrium conditions [17]. Several meters behind the beach lies several walkways which bisect the vegetated foredune and a road parallel to the shoreline which separates the houses from the sandy shore.

\subsubsection{Cullendulla Beach}

Cullendulla Beach is located at the confluence between Cullendulla Creek and Batemans Bay. The beach is embayed on both ends by Square Head to the east and Hawk's Nest Head to the west. Though the entire span of the beach is $891 \mathrm{~m}$ long with a width of $25 \mathrm{~m}$ and a dune height of $2 \mathrm{~m}$, only the western leg of the beach, which is exposed to wave activity, will be investigated. The beach faces due south east with a $215^{\circ}$ orientation. Though the beach is protected from wave activity, the beach is exposed to the river flow from Cullendulla Creek, which acts as an erosive agent [17]. Wave refraction due to Square Head causes longshore drift of sediment from the west to east end of the beach, forming a large ebb-tide delta [17], which can be observed in Figure 2. Cullendulla Beach is somewhat isolated from anthropogenic activity as it lies in front of the Cullendulla Nature Reserve, 
which is a sandy plain of successive foredune ridges colonized by Casuarina-dominated forest interspersed with mangrove swamps.

(a)

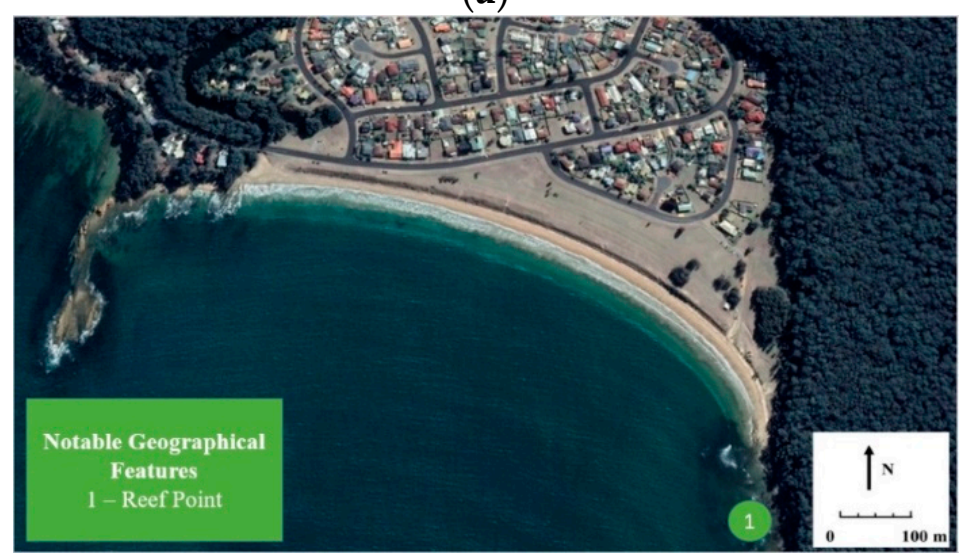

(b)

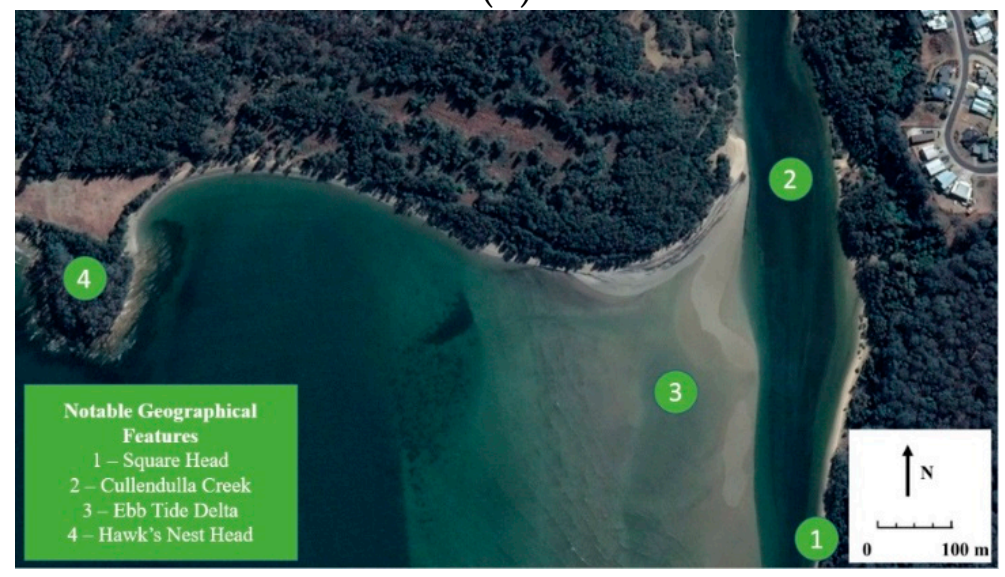

(c)

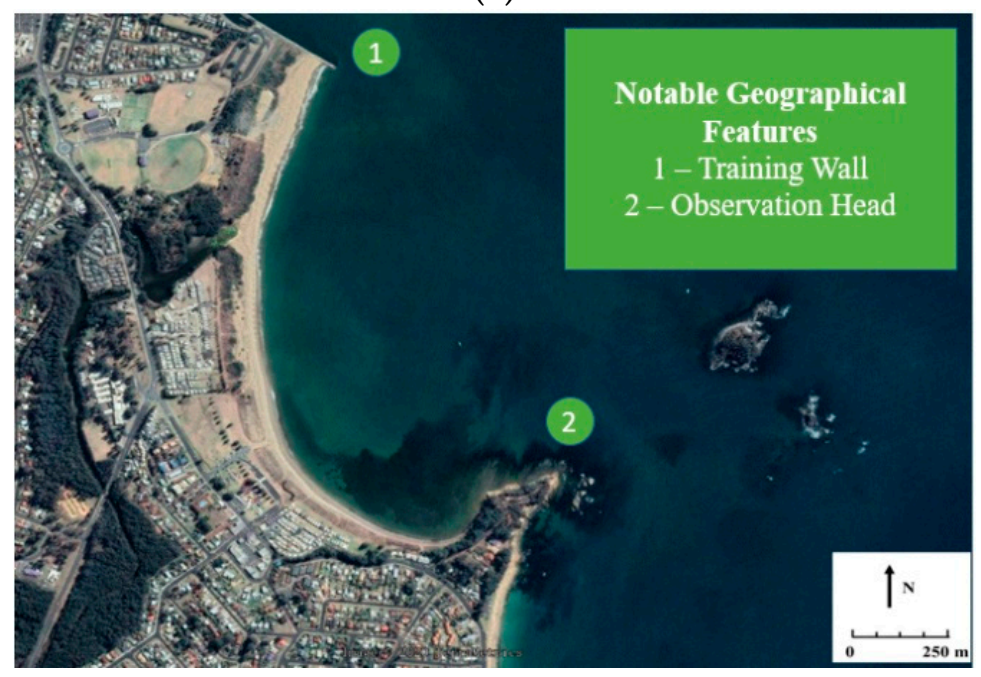

Figure 2. (a) Maloney's Beach: $35.7096^{\circ}$ S, $150.2461^{\circ} \mathrm{E}$; (b) Cullendulla Beach" $35.7007^{\circ} \mathrm{S}, 150.2021^{\circ}$ E; and (c) Corrigans Beach: $35.7309^{\circ}$ S, $150.2005^{\circ}$ E (source: Google Earth 2020). 


\subsubsection{Corrigans Beach}

Corrigans Beach is located on the south side of Batemans Bay. The beach spans $1.84 \mathrm{~km}$ in length, with a width of $110 \mathrm{~m}$ and a dune height of $2.5 \mathrm{~m}$, and faces northeast at a $60^{\circ}$ angle. Corrigans Beach is embayed by Observation Head at the south end and an artificial training wall at the north end [19]. Corrigans Beach is a manmade beach, having formed since the construction of the first training wall in 1905 and subsequent extensions. As a result of the training wall at the northern end, the beach is slowly accreting. A low-lying sandy plain is present behind the active shoreline, suggesting that it is a depositional beach Wave refraction due to Observation Head at the south results in longshore drift from the southern end of the beach to the northern end [17].

\section{Methodology}

To investigate the impacts of storms on the selected sites, two types of data were collected. Primary and secondary beach profiles were recorded to identify beach trends. Weather and oceanographic data were taken to confirm storm activity and corroborate beach trends with storm activity.

\subsection{Beach Profiling}

\subsubsection{Field Data}

At each study site, a beach elevation profile was measured (in meters) with a vertical resolution of $0.01 \mathrm{~m}$ from a designated datum point to the water line. The datum point and orientation were selected to align with historic beach profiles. The beach profiles were recorded approximately fortnightly over an 8-week period, from 2019-12-10 to 202002-12. Additionally, a control measurement was taken on 2019-8-31 to create a seasonal comparative.

Beach profiles were recorded with a Dumpy Level and a $5 \mathrm{~m}$ Levelling Staff with $1 \mathrm{~cm}$ increments. The Dumpy Level was placed at a set position and measurements were read off the Levelling Staff from the datum point to shoreline, with additional interim points for consistency or to measure observed gradient changes.

\subsubsection{Historic Beach Profiles}

Historic beach elevation profiles are available from the Water Research Laboratory as part of the NSW Beach Profile Database. The database includes historic beach profiles dating from 1942 to 2018 for all three beaches. The historic profiles are divided into blocks of parallel beach profiles perpendicular to the shoreline. These profiles are derived from stereo airphoto photogrammetry used to create a 3D model. The Maloney's Beach site was compared to Block E Profile 8 (Figure 3a). The West Cullendulla Beach site was compared to Block Y Profile 1 (Figure 3b). The South Corrigans Beach site was compared to Block X Profile 23 (Figure 3c). The archive of the stereo airphoto photogrammetry does not provide the uncertainty of this method. However, a study by Del Rio and Gracia (2013) [20] shows that the total error in the rate of shoreline change based on photogrammetry can reach \pm 0.22 /year. Our rate of shoreline changes (e.g., Cullendulla Beach from 1993 to 2011) is $1 \mathrm{~m} /$ year, which is clearly larger than this threshold value (see below). 
(a)

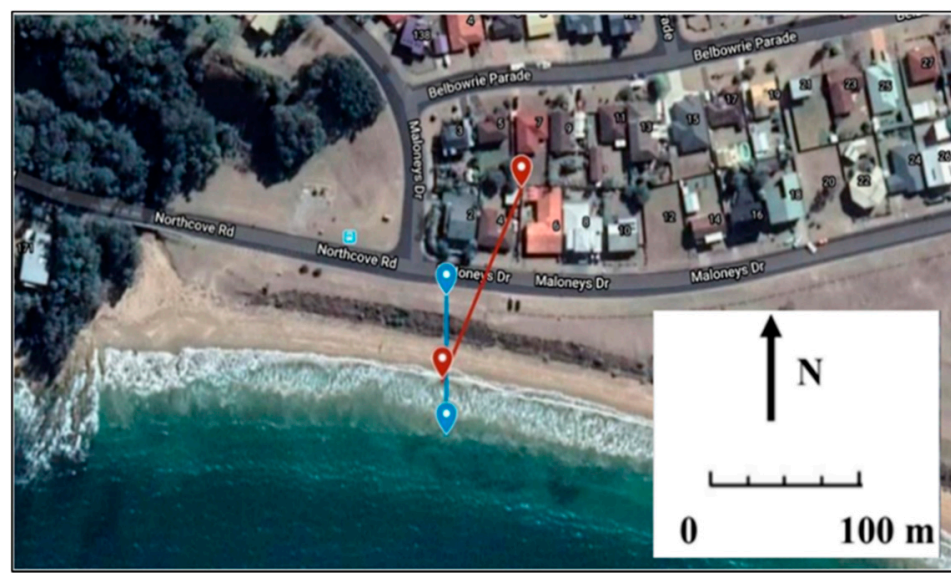

(b)

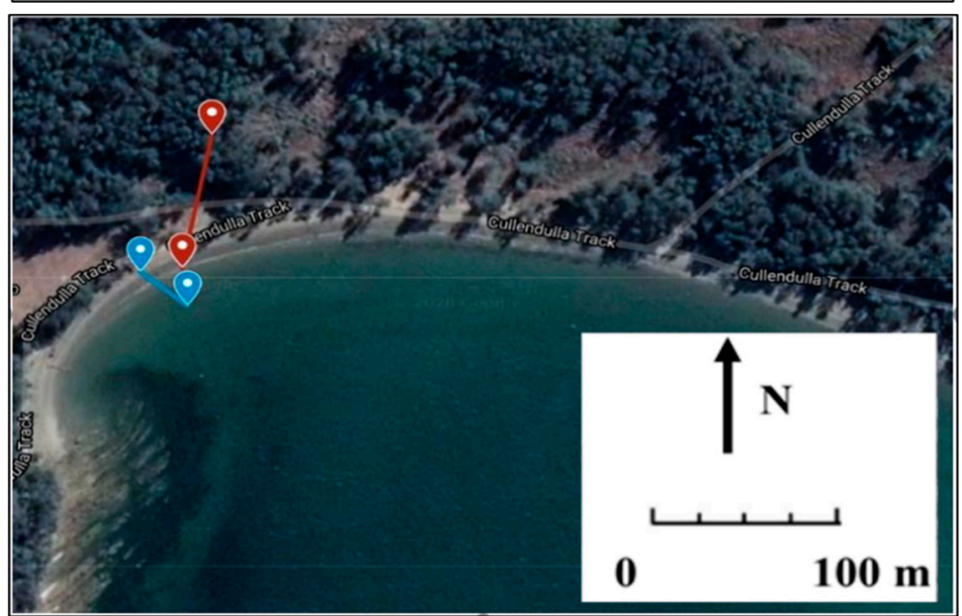

(c)

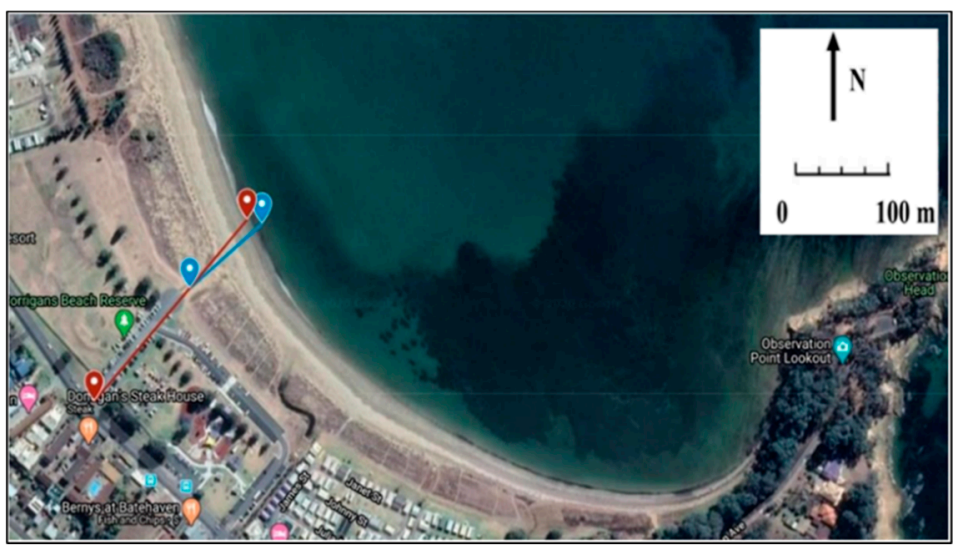

Figure 3. (a) Maloney's Beach, with field data profiles marked in blue and 2018 Block E Profile 8 marked in red; (b) West Cullendulla Beach, with field data profiles marked in blue and 2018 Block Y Profile 1 marked in red; and (c) South Corrigans Beach, with field data profiles marked in blue and 2018 Block X Profile 23 marked in red (source: Google Maps).

\subsection{Weather and Oceanographic Data}

\subsubsection{Wave Data and Model}

The wave direction and wave height for the duration of the field observations, as well as the historic data, were obtained through publicly accessible data from the Manly Hydraulics Lab (https: / mhl.nsw.gov.au/ Accessed on 15 February 2020) Directional Waverider Buoy located at $35.7031^{\circ} \mathrm{S}, 150.3439^{\circ} \mathrm{E}$. Hourly historic wave height and direction data from 2001-02-23 to 2020-03-27 were accessed through a data request. A wave model of the Batemans Bay coast area was developed using the SWAN Model 
(http: / / swanmodel.sourceforge.net/ Accessed on 20 February 2020) employing this data. Wave models measuring a significant wave height and wave-induced bottom stress were simulated for the prevailing summer winds of south-easterly (SE) and prevailing winter winds of south-westerly (SW) (see Section 4.2.1), with a constant wind speed of $25.7 \mathrm{~m} / \mathrm{s}$. This value is a recorded daily average wind speed measured during the 2004-01-21 storm event in the Bay (also see Section 4.4). A constant swell of $2 \mathrm{~m}$ with a period of $10 \mathrm{~s}$ was also used for the wave model open boundary condition offshore for this part of the NSW coast (Vila-Concejo et al., 2010). It should be noted that model runs with or without swell at the open boundary yield less than a $0.1 \mathrm{~m}$ difference in its wave height inside the bay as the wave model offshore boundary is about $100 \mathrm{~km}$ away.

\subsubsection{Wind Data}

The wind speed and direction were recorded approximately $20 \mathrm{~km}$ away from Batemans Bay at the Moruya Airport Weather Station and accessed via the Bureau of Meteorology (http:/ / www.bom.gov.au/places/nsw/batemans-bay/ Accessed on 12 February 2020). Historic three-hourly data were requested from the Bureau of Meteorology for the period from 1957-01-01 until 2020-03-28.

\subsubsection{Tide}

Hourly tide data were recorded from the Princess Jetty Buoy in Batemans Bay, which are publicly accessible from the Manly Hydraulics Lab (http:/ / nearshore.waves.nsw.gov. au/index.php Accessed on 12 February 2020). Beach profiles were only recorded at low tide, to allow us to capture the full profile; however, sea level changes in sub-tidal periods are expected in accordance with spring-neap cycles.

\subsubsection{Storm Records}

The Bureau of Meteorology has a publicly accessible "Severe Storms Archive" (http:/ / www.bom.gov.au/australia/stormarchive/ Accessed on 12 February 2020), which has recorded six historic storms under the location tag of "BATEMANS BAY" since 1947.

\section{Results}

\subsection{Primary Beach Profiles}

As shown in Figure 4a,c, Maloney's Beach and South Corrigans Beach remained generally stable, regardless of storm conditions prior to the 2020-02-12 profile. Cullendulla showed consistent shoreline recession, which increased after the ECL event (Figure 4b). All beaches exhibited seasonal differences; the late winter measurement on 2019-08-31 was significantly narrower than later summer measurements. This difference was most pronounced for the Cullendulla Beach and Maloney's Beach in the north of Batemans Bay. 
(a)

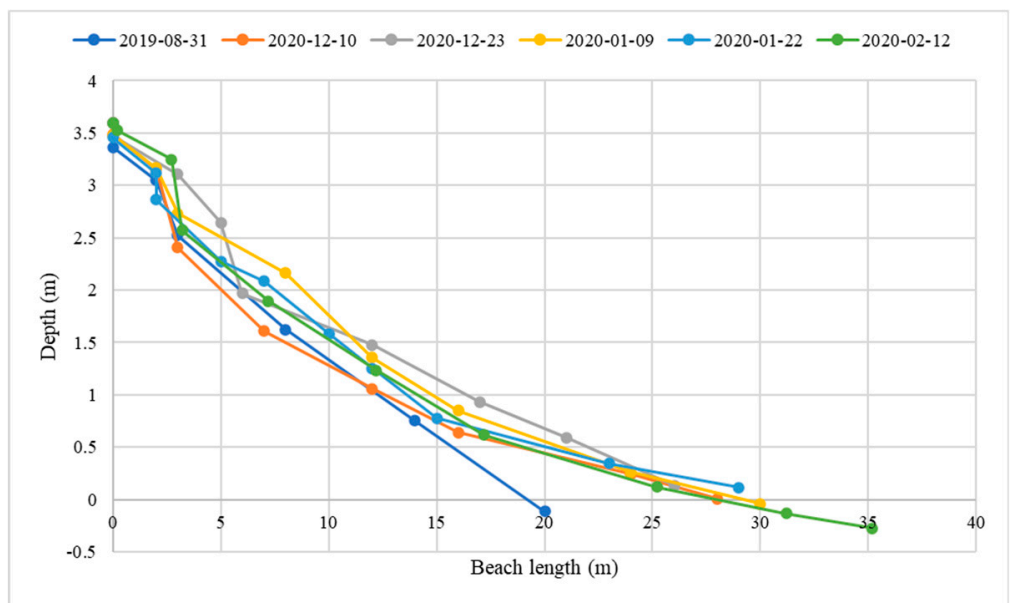

(b)

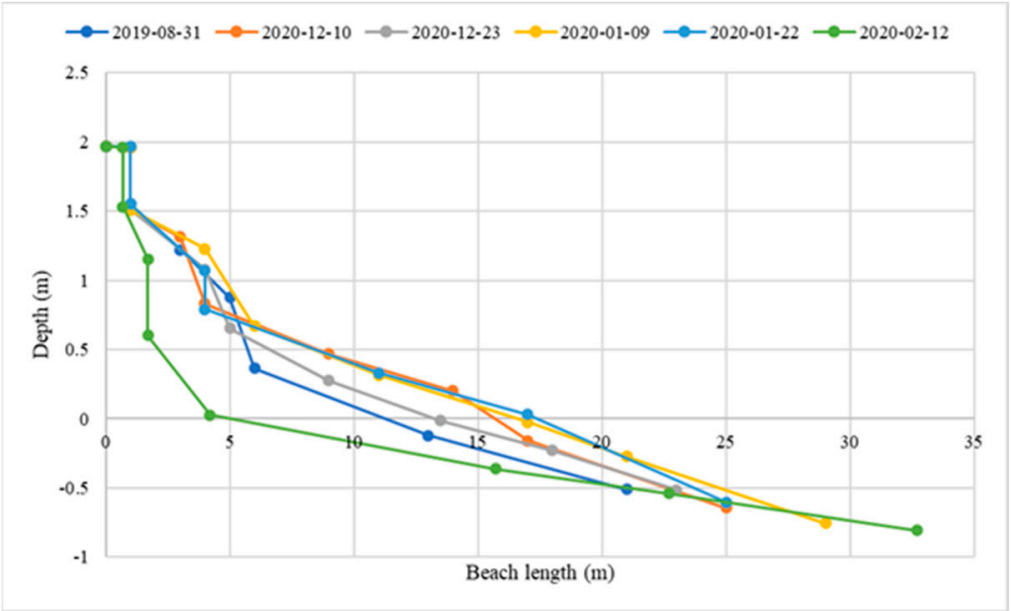

(c)

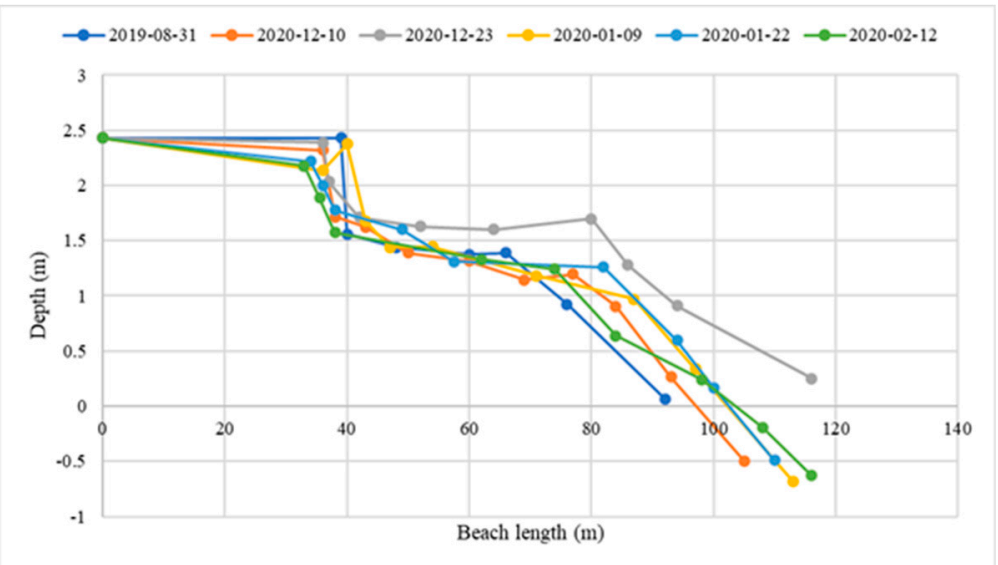

Figure 4. (a) Maloney's Beach profiles from 2019-08-31 to 2020-02-12; (b) Cullendulla Beach profiles from 2019-08-31 to 2020-02-12; and (c) Corrigans Beach profiles from 2019-08-31 to 2020-02-12.

\subsection{Wind and Wave Data}

Table 1 shows average significant wave height $(\mathrm{Hs})$ and wind data recorded on the date of beach profile surveys from 2019-8-31 to 2020-02-12. The wave and wind data were measured by the Waverider Buoy at $35.7031^{\circ} \mathrm{S}, 150.3439^{\circ} \mathrm{E}$ and the Moruya Airport weather station, respectively. While conditions were relatively similar throughout the measurement period, it should be noted that the 2020-02-12 profile occurred just after an ECL windstorm, which made landfall in Batemans Bay late on 2020-02-08 and continued 
through to 2020-2-10. The wind speed and wave height values were significantly higher than those of the historic average, as shown in Table 2.

Table 1. Average wave and wind data recorded on the date of the profile from the $35.7031^{\circ} \mathrm{S}$, $150.3439^{\circ}$ E Waverider Buoy and the Moruya Airport weather station.

\begin{tabular}{ccccc}
\hline Date of Survey & $\begin{array}{c}\text { Average } \\
\text { Hs (m) }\end{array}$ & $\begin{array}{c}\text { Average Wave } \\
\text { Direction }(\mathbf{d e g})\end{array}$ & $\begin{array}{c}\text { Average Wind } \\
\text { Speed (m/s) }\end{array}$ & $\begin{array}{c}\text { Average Wind } \\
\text { Direction (deg) }\end{array}$ \\
\hline $2019-08-31$ & 1.72 & 151.39 & 3.29 & 184.13 \\
$2019-12-10$ & 1.65 & 111.46 & 3.48 & 162.13 \\
$2019-12-23$ & 1.56 & 153.91 & 4.05 & 61.88 \\
$2020-01-09$ & 0.92 & 135.11 & 3.16 & 143.25 \\
$2020-01-22$ & 1.53 & 108.57 & 4.76 & 27.38 \\
$2020-02-12$ & 1.73 & 111.25 & 4.00 & 185.88 \\
\hline
\end{tabular}

Table 2. Wave and wind data for an East Coast Lows (ECL) event compared to the historic average from the $35.7031^{\circ} \mathrm{S}, 150.3439^{\circ} \mathrm{E}$ Waverider Buoy and the Moruya Airport weather station.

\begin{tabular}{ccccc}
\hline Date & $\begin{array}{c}\text { Average } \\
\text { Hs (m) }\end{array}$ & $\begin{array}{c}\text { Average Wave } \\
\text { Direction } \mathbf{( d e g})\end{array}$ & $\begin{array}{c}\text { Average Wind } \\
\text { Speed (m/s) }\end{array}$ & $\begin{array}{c}\text { Average Wind } \\
\text { Direction (deg) }\end{array}$ \\
\hline 2020-02-09 & 4.02 & 110.52 & 8.10 & 101.88 \\
2020-02-10 & 3.68 & 104.91 & 4.69 & 65.88 \\
Historic Data Average & 1.43 & - & 3.23 & - \\
\hline
\end{tabular}

\subsubsection{Historic Wind Data}

As shown in Figure 5, historic wind data reveal that the average wind speed is higher in summer seasons and lower in winter seasons. Summer winds blow south-easterly, whereas in winter, the wind blows south-westerly. Meanwhile, winds generally blow southerly in spring and autumn. South-westerly winter winds are likely slower due to The Great Dividing Range southeast of Batemans Bay, which acts as a wind break.

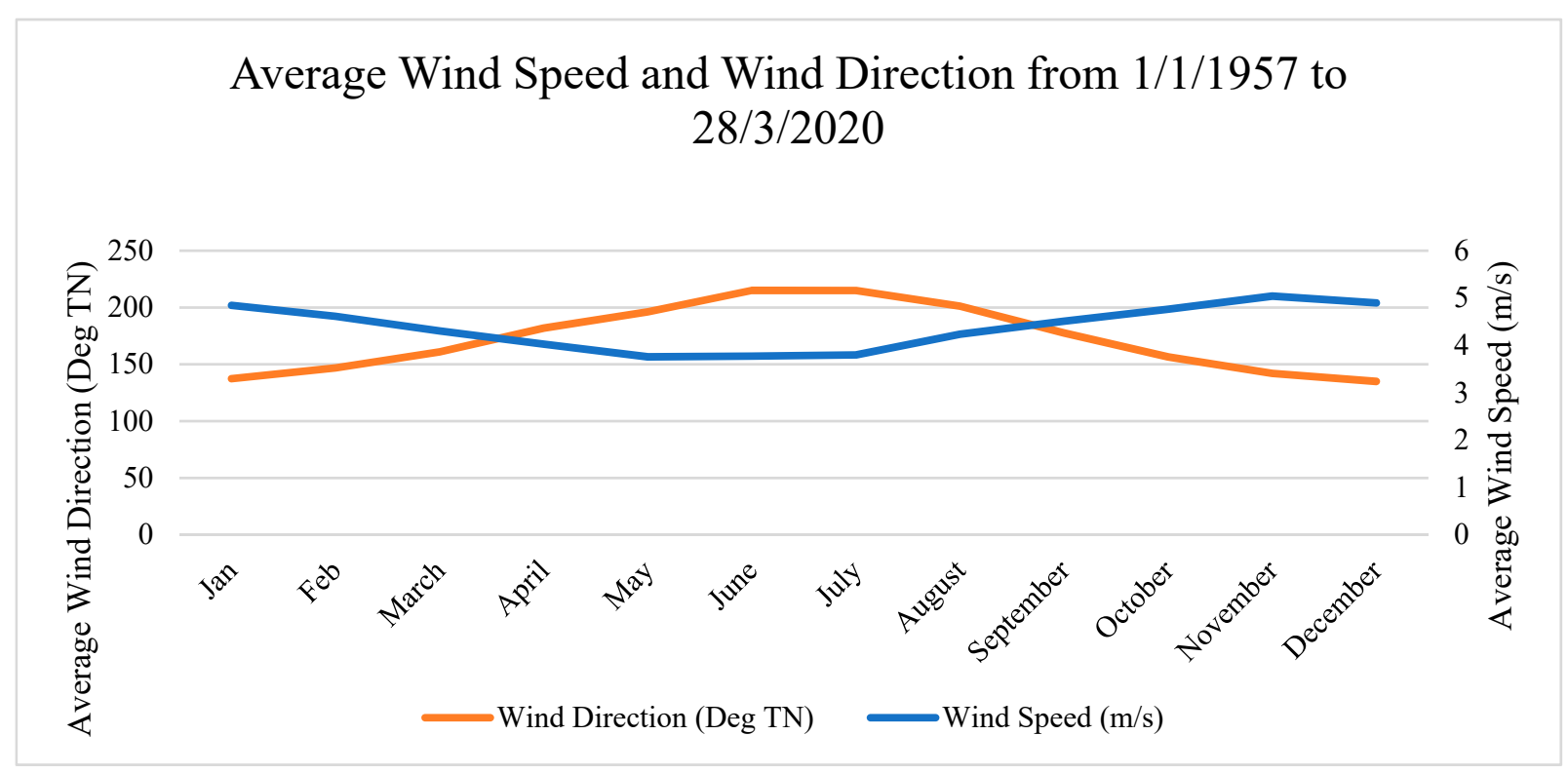

Figure 5. Graph of the average wind speed and wind direction from 1957-01-01 to 2020-03-28 from the Moruya Airport weather station. 


\subsection{SWAN Modeling}

\subsubsection{Modeled Wave Height}

Summer storm winds blow from the southeast toward the estuary, causing waves to run perpendicular to the bay entrance (Figure 6). Therefore, the wind fetch is maximized within the bay, the wave height is increased, and the waves have more energy. Significant diffraction due to the Tollgate Islands occurs to the south east of Batemans Bay, causing the wave height to decrease behind the islands. All three beaches are protected by a southern or eastern headland, which refracts waves and shelters the beach. As summer winds enter further into the bay, summer storms can be more impactful than winter storms.
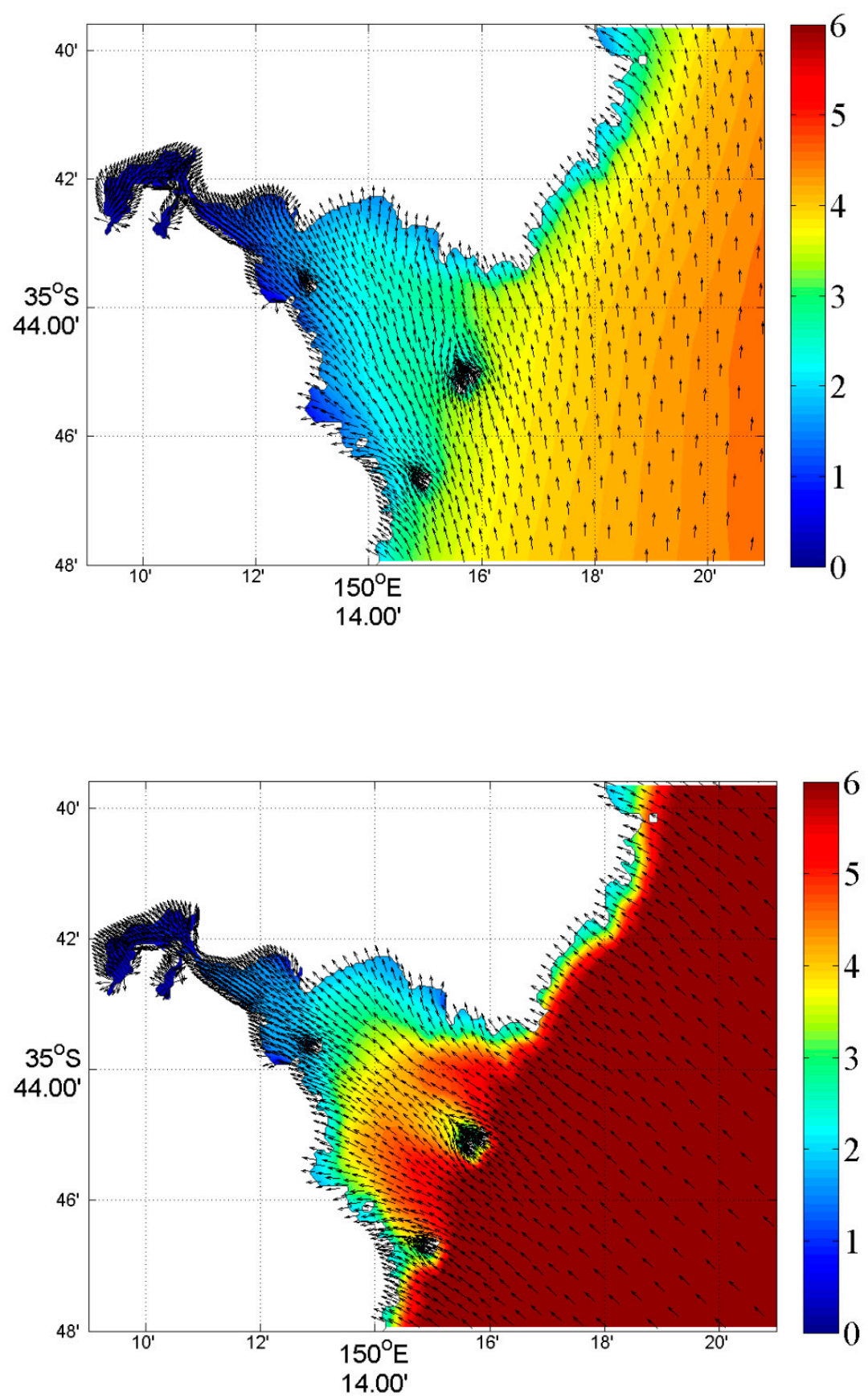

Figure 6. Model predicted a significant wave height and direction for prevailing south-westerly winter winds (top) and prevailing south-easterly summer winds (bottom), with a constant storm wind speed of $25.7 \mathrm{~m} / \mathrm{s}$. The wave direction is indicated by vectors. 
Winter winds blow towards the northern coast from the southwest. Overall, winter wave heights are lower than summer wave heights, and the wave height is substantially lower at the south of the bay. As Maloney's Beach experiences the greatest wave heights in winter, storm erosion may be localized to northern beaches.

\subsubsection{Wave-Induced Bottom Stress}

Figure 7 shows the model-simulated wave bottom stress, which is a measure of friction upon the seabed by waves. Higher bottom stress occurs nearer to the coast because it is shallower, allowing waves to apply greater force to the seabed. The amount of bottom stress needed to resuspend sediment and erode it is the critical bed sheer stress (CBSS).
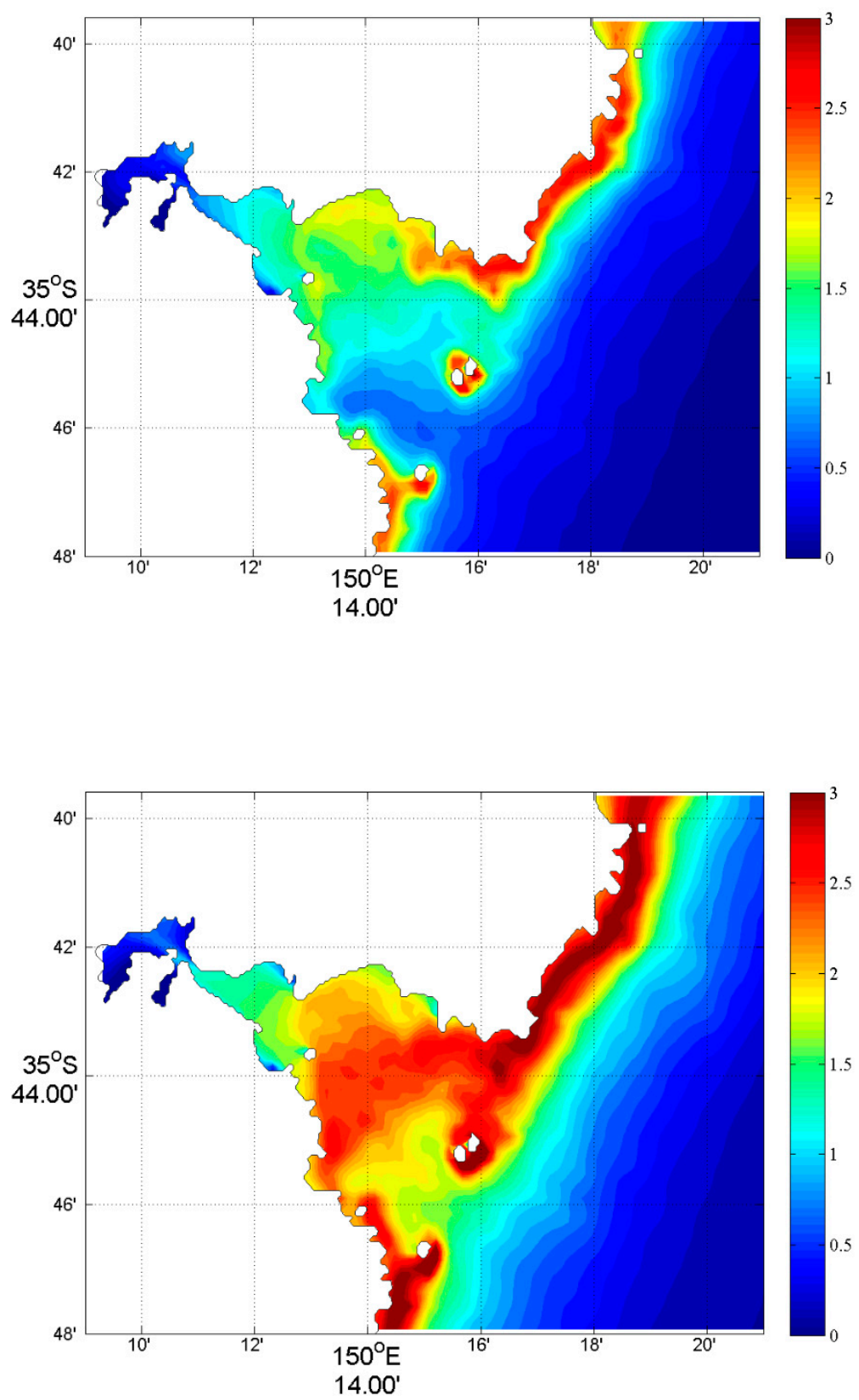

Figure 7. Model-predicted wave-induced bottom stress for prevailing south-westerly winter winds (top) and prevailing south-easterly summer winds (bottom), with a constant storm wind speed of $25.7 \mathrm{~m} / \mathrm{s}$. 
Like the wave height, Batemans Bay experiences the most wave-induced bottom stress when the wind is blowing perpendicular to the bay entrance, combined with ocean waves entering the bay. Therefore, the bottom stress is the highest in summer seasons and significantly lower in winter seasons. This suggests that a storm in summer provides the greatest potential for beach erosion, as well as sediment transport onshore, when bottom stress is more likely to exceed CBSS.

\subsection{Storm Records}

Six storm incidents were reported from the Severe Storm Archive in Batemans Bay, as shown in Table 3. Storms are generally categorized under seven tags (Rain, Hail, Wind, Tornado, Lightning, Waterspout, and Dust Devil). Further information about storm categorization can be found at http:/ / www.bom.gov.au/australia/stormarchive/about. shtml (Accessed on 12 February 2020).

Table 3. Storm events under the "BATEMANS BAY" locational tag.

\begin{tabular}{cccc}
\hline Storm Type & Date & $\begin{array}{c}\text { Maximum Wind } \\
\text { Speed }(\mathbf{m} / \mathbf{s})\end{array}$ & $\begin{array}{c}\text { Maximum Wave } \\
\text { Height }(\mathbf{m})\end{array}$ \\
\hline Hail & $1994-09-1307: 15: 00$ & 16.6 & NO DATA \\
Rain/Wind & 1998-12-14 06:30:00 & 40.7 & NO DATA \\
Rain & 1999-01-27 22:00:00 & 22.3 & NO DATA \\
Rain/Hail/Wind & 2004-01-21 08:55:00 & 51.8 & 2.798 \\
Hail & 2004-01-30 03:30:00 & 11.2 & 2.388 \\
Hail & 2005-01-15 07:40:00 & 29.5 & 3.228 \\
\hline
\end{tabular}

The 1998-12-14 storm event and 2004-01-21 storm event were "Wind" storm types and recorded a daily average wind gust speed of 33.4 and $25.7 \mathrm{~m} / \mathrm{s}$, respectively. "Wind" storm events are defined by the Bureau of Meteorology as a "Severe Wind Gust", but not "Severe winds at sea" and are most comparable to local wind fetch events.

If storms have a long-term (interannual) impact on Batemans Bay beaches, historical beach profiles after the storm event should show a response. Due to the sporadic nature of the historic beach profiles, the impacts of these storm events can be best gauged through indicator profiles of 1993-04-15, 1999-02-06, and 2007-03-28. The 1993 profile represents the beach shape before the 1998-12-14 storm, the 1999 profile represents the beach shape after the 1998-12-14 storm and before the 2004-01-21 storm, and the 2007 profile represents the shape after the 2004-01-21 storm.

\subsection{Beach Historical Data}

\subsubsection{Maloney's Beach}

The field data findings are supported by historic beach profiles. The beach profiles show very little long-term change, except for the 1942 beach profile, which was recorded prior to development on hind dunes (Figure 8a). No significant changes were recorded in the three storm indicator profiles.

\subsubsection{Cullendulla Beach}

The historic beach profiles generally support the shoreline recession detected in the field data. However, although the field data indicated significant storm-related erosion, this type of erosion may occur in the short term as the three storm indicator profiles displayed little erosion in comparison to previous profiles. In contrast, the 2011-05-15 and 1977-03-14 profiles exhibited significant erosion in comparison to the previous profiles, yet no storm was recorded. This indicates that Cullendulla Beach faces other erosional pressures. 


\subsubsection{Corrigans Beach}

Contrary to the field data, the long-term beach profiles demonstrate that early erosive behavior from 1942 to 1962 was proceeded by substantial accretion up to 1972. Further accretion occurred when the training wall was extended in 1991. Long-term accretion trends occurred regardless of storm events, as revealed by the three storm indicator profiles.

8

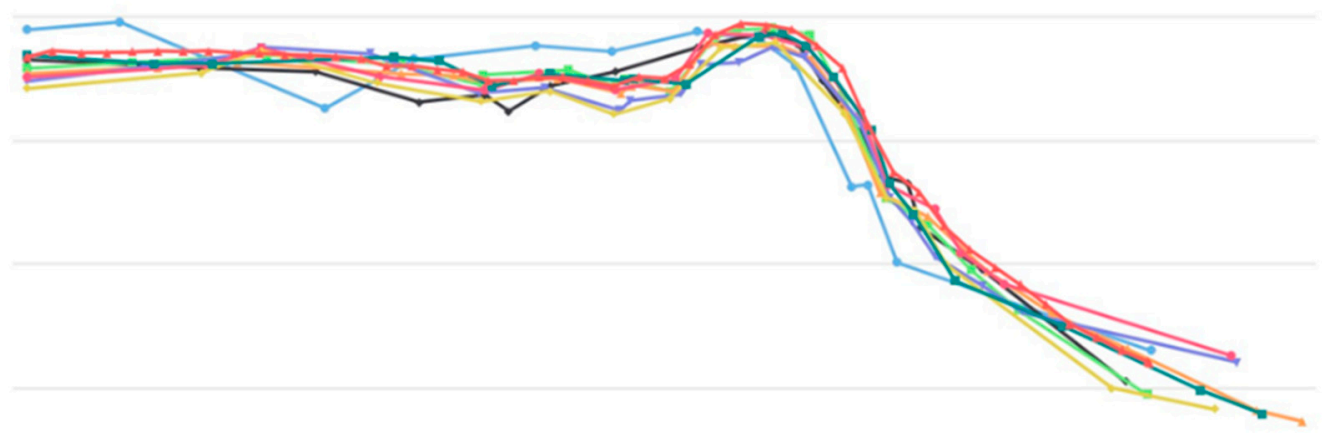

$-2$

$10 \quad 20 \quad 30$

40

50

60

70

80

90

100

Chainage $(\mathrm{m})$

- Block E, Profile 8, 1942-06-22 - Block E, Profile 8, 1972-05-03 - Block E, Profile 8, 1990-04-29

- Block E, Profile 8, 1993-04-15 - Block E, Profile 8, 1999-02-06 - Block E, Profile 8, 2007-03-28

- Block E, Profile 8, 2011-05-15 - Block E, Profile 8, 2014-11-27 - Block E, Profile 8, 2018-09-10

Highcharts.com

3

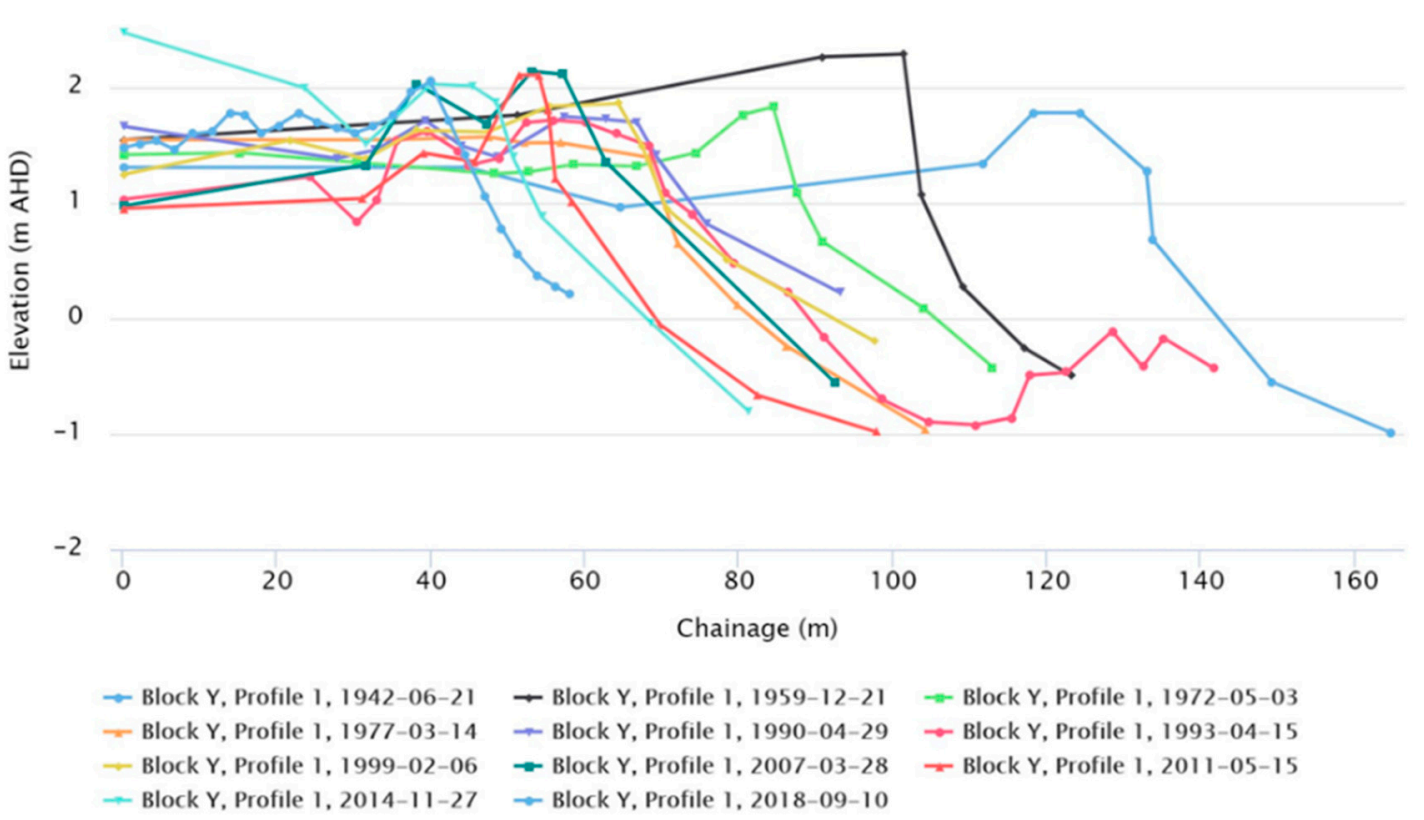

Figure 8. Cont. 


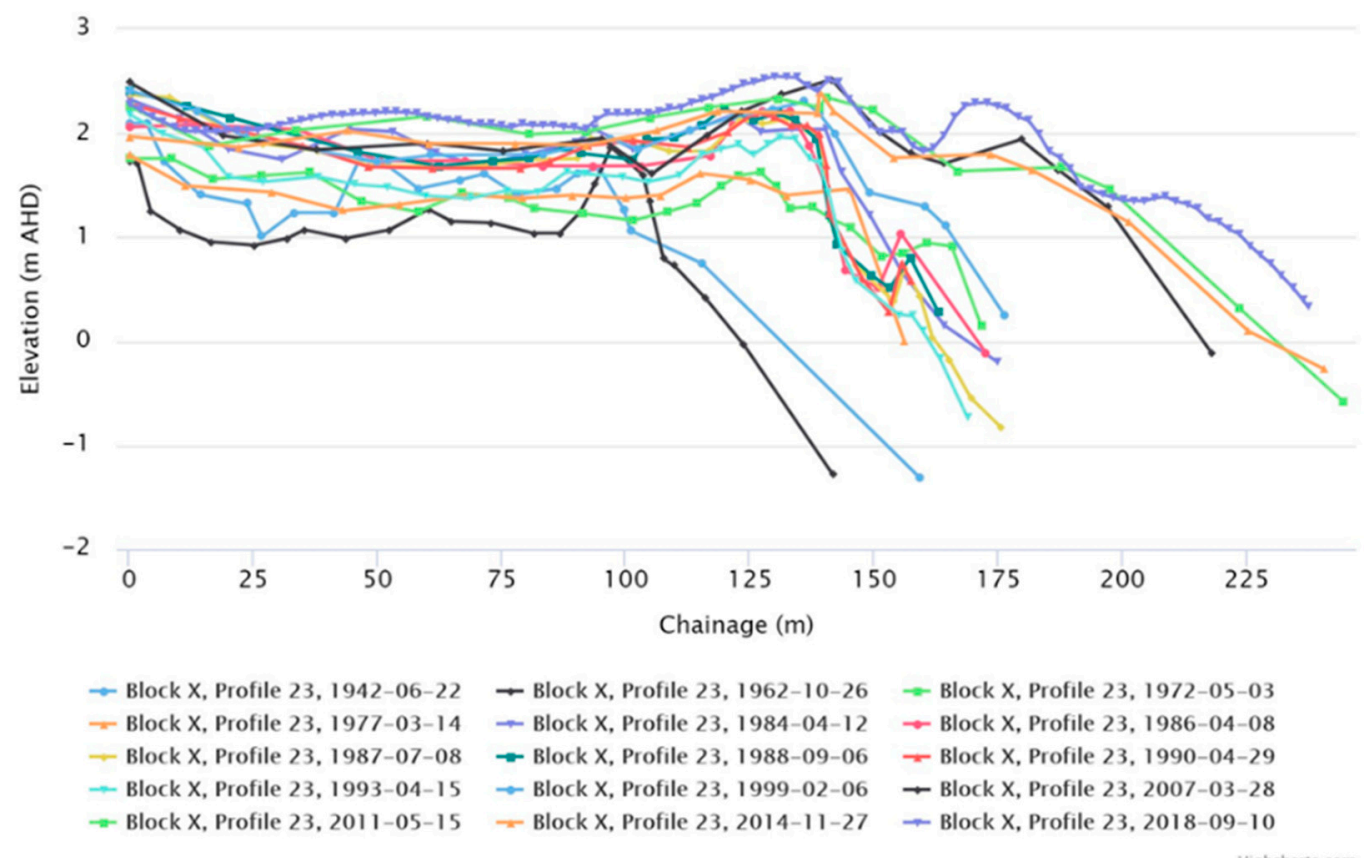

Figure 8. Historic beach profile for (a) Maloney's Beach Block E Profile 8 from 1942-06-22 to 2018-09-10; (b) Cullendulla Beach Block Y Profile 1 from 1942 to 2018; and (c) Corrigans Beach Block X Profile 23 from 1942 to 2018 (Source: http: / / www.nswbpd.wrl.unsw.edu.au/photogrammetry/nsw/ Accessed on 12 February 2020).

\section{Discussion}

\subsection{Short-Term Storm Susceptibility}

During the field data period, an easterly ECL event was recorded from 2020-02-09 to 2020-02-10. The event had an average recurrence interval (ARI) "equivalent to a 5- to 10-year ARI with respect to rainfall at Sydney" [21]. However, the ECL event had little to no effect on both Maloney's Beach and Corrigans Beach.

This is likely due to the easterly wind and wave conditions resulting in Reef Point and Observation Head sheltering the respective beach. In both cases, the wave energy was significantly decreased, resulting in no change in the beach profile.

Alternatively, Cullendulla Beach decreased significantly in terms of the beach length compared to the 2020-01-22 profile, despite the low-impact easterly wind and wave direction and the presence of a large headland to the east of Cullendulla. This suggests that the storm response on Cullendulla Beach could be due to factors unrelated to wave impacts, corroborating the observations made from historic data. Possible alternative factors will be discussed below. Additionally, the beach displayed qualitative changes, including fallen trees and washed up algal blooms, likely from Cullendulla Creek, as shown in Figure 9.

Previous studies have indicated that wave refraction due to Square Head causes longshore drift from the western end of Cullendulla Beach towards the delta between Cullendulla Creek and Batemans Bay [22]. Storm activity is likely to heighten this process, resulting in erosion due to an ECL event.

Overall, it can be said that while embayed beaches in Batemans Bay are generally resilient to easterly storm events, existing erosional longshore drift trends may be strengthened. Additionally, based on Figures 5 and 6, it can be assumed that more south-easterly directed storm events may result in greater storm impacts as all beaches experience a greater wave height and bottom stress. 

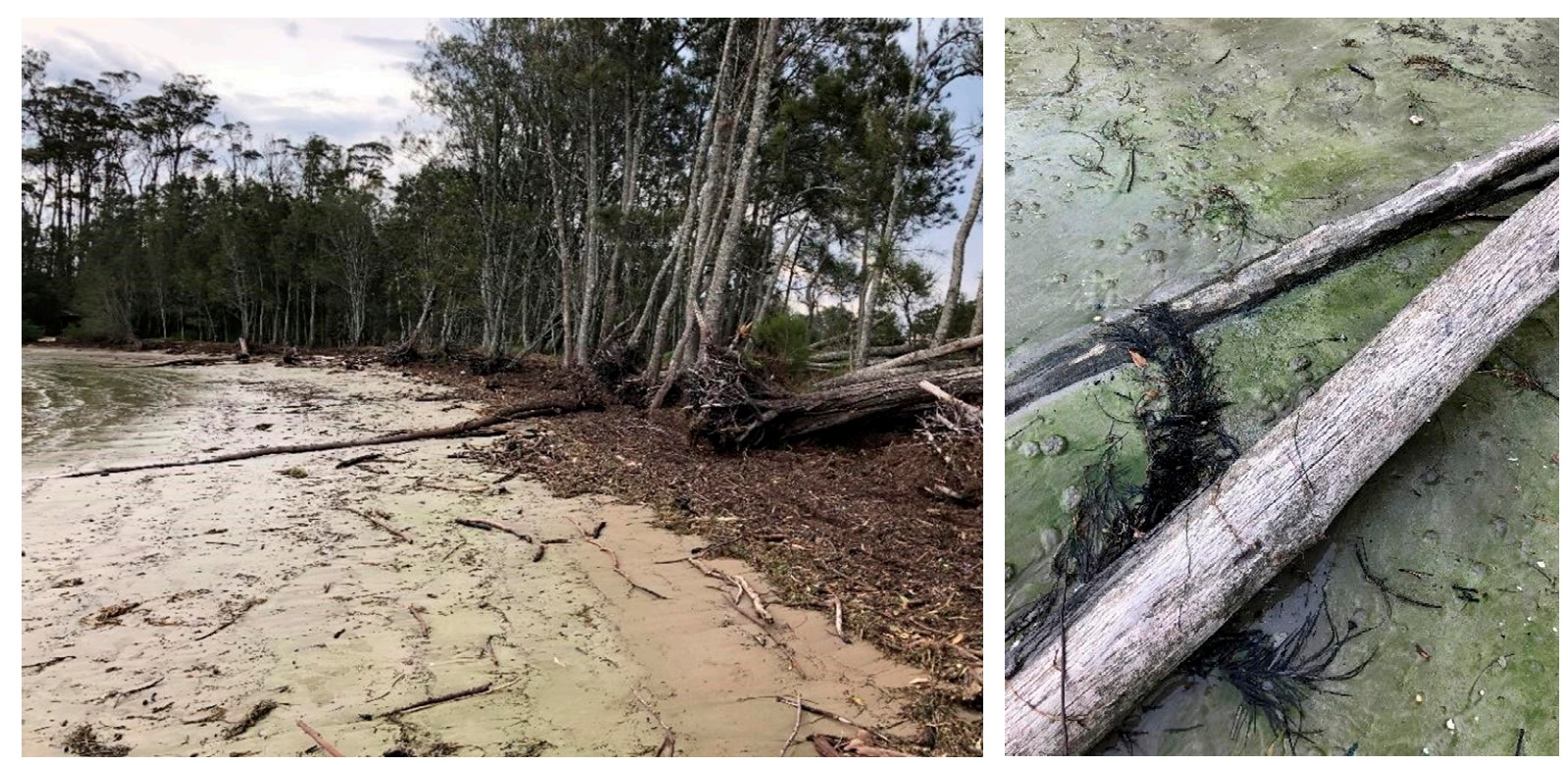

Figure 9. Trees knocked over due to an ECL event (left) and the presence of algal blooms (right), with the photos having been taken on $2020-02-12$ at $35.7144^{\circ} \mathrm{S}, 150.1795^{\circ} \mathrm{E}$.

\subsection{Seasonal Changes in the Storm Response}

The field data show that all three embayed beaches experienced significant accretion between the winter 2019-8-31 profile and 2020 summer profiles. This can be explained by the relatively lower bottom stress from swell waves in winter seasons.

Cooper et al. (2004) [23] argued that there is a correlation between bottom stress and beach behavior. In their study of storm impacts on three embayed, high-energy beaches in western Ireland, they demonstrated that bottom sediment offshore can be resuspended by wave-induced bottom stress and transported onshore to the beaches, as indicated by vectors of wave-induced stress. They showed that maximum transport values occur on the highest sections of the ebb-tidal delta, along the shoreline and at the apex of the headland. In Batemans Bay, as shown in Figure 6, winter south-westerly winds create waves that have lower offshore bottom stress. Additionally, the bottom stress predicted by the model $\left(0.5 \mathrm{~N} / \mathrm{m}^{2}\right)$ uses a wind speed of $25.7 \mathrm{~m} / \mathrm{s}$, whereas the average windspeed during winter months is $3.93 \mathrm{~m} / \mathrm{s}$. Therefore, it can be inferred that bottom stress will be substantially lower than model predictions. As a result, winter swell waves are likely under the CBSS thresholds (which can be calculated by the Shields function to be approximately $0.2 \mathrm{~N} / \mathrm{m}^{2}$ for each beach), and waves are unable to suspend sand from the bottom and rebuild the beach. During the summer, south-easterly swell waves have a longer fetch period and windspeeds are higher. As a result, bottom stress is increased, allowing the resuspension of bottom sediment offshore and reconstruction of the beach. Therefore, though summer storms are likely to have a greater short-term erosive impact due to southeasterly prevailing winds, these impacts are offset by the greater reconstructive potential summer swell waves have. This explains the accretion between the winter 2019-8-31 profile and 2020 summer profiles. This may also explain the lack of any significant storm response in the three storm indicator profiles of 1993, 1999, and 2007 as all three profiles were recorded in either summer or early autumn. Although south-easterly summer storms are more likely to cause beach erosion on the embayed beaches, these impacts are mitigated by the reconstructive summer swell waves. 


\subsection{Long-Term Sediment Trends}

\subsubsection{Maloney's Beach and Corrigans Beach}

At a long-term scale, both Maloney's Beach and Corrigans Beach showed little to no susceptibility to storm events, as suggested by the historic profiles. In both cases, embayment characteristics limited storm impacts and any other agents of erosion.

Maloney's Beach appears to be in a state of equilibrium, with almost no changes in the historic beach profiles. This is primarily due to longshore drift being limited to the embayed area, resulting in no net loss of sediment.

Corrigans Beach shows signs of long-term accretion, especially at the northern end (figure for northern profiles not shown). This is related to the artificial embayment of northern Corrigans Beach by a training wall constructed in 1905 and its subsequent extensions and the accompanying dredging from 1905 until 1955 [17]. As a result, the channel from the mouth of Clyde's River along the training wall is 10-20 $\mathrm{m}$ deep and significantly deeper than the rest of the bay (Figure 10). As a result of the training wall, "80 per cent of the sand supplied by the Clyde River into the inner bay had accreted on Corrigans Beach" [24] and "at least $650,000 \mathrm{~m}^{3}$ of sand accumulated in the lee of the wall to accrete the shoreline up to $600 \mathrm{~m}$ into the bay and build Corrigans Beach" [25]. The channel along the training wall was dredged again in 2016, strengthening these accretion trends.

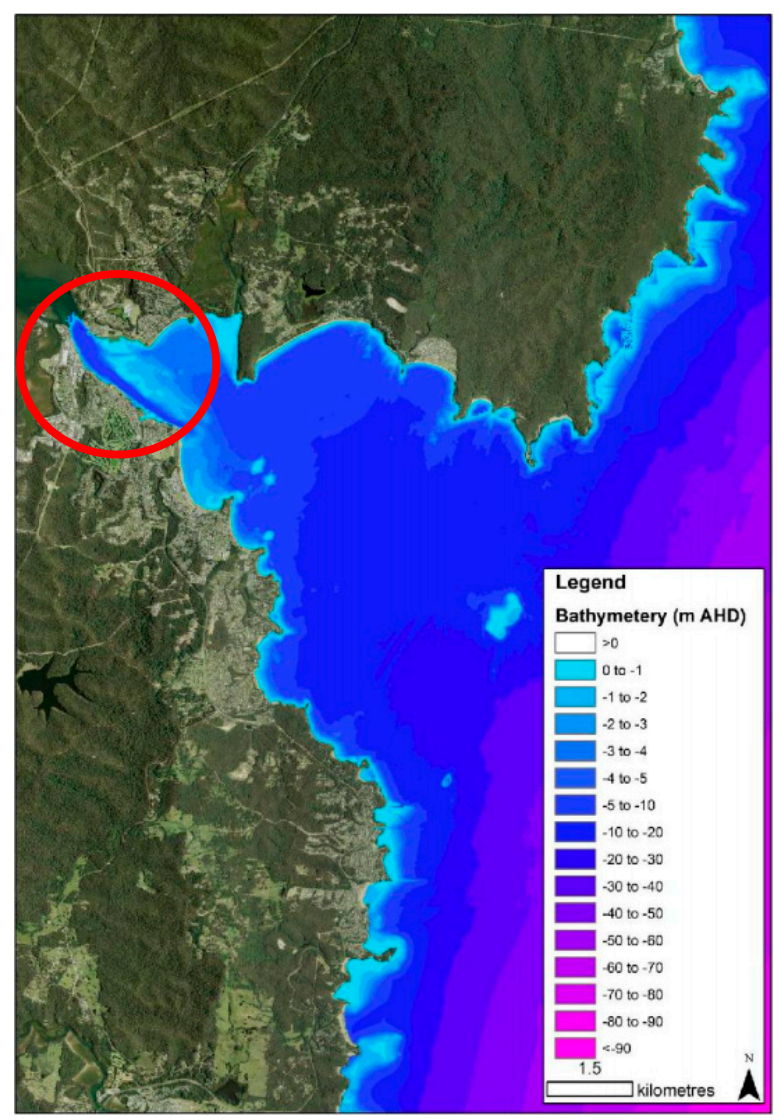

Figure 10. 2017 bathymetry data for Batemans Bay, with the deepened channel circled in red (Water Research Laboratory, 2017).

\subsubsection{Cullendulla Beach}

Cullendulla Beach was the embayed beach that showed the most long-term recession over the historic data. However, long-term erosion of Cullendulla Beach is likely not caused by storm events. Instead, erosion was dependent on a few factors. First, the "supply of sand to Cullendulla Beach is probably dependent on a combination of intense flood events and wave-induced current circulation" [26] to transport sediment from Surfside Beach (Figure 1). 
This is due to the obstruction of sediment transfer from Surfside Beach to Cullendulla Beach by Hawk's Nest Head. Sediment transfer can only occur during low ARI intense flood events and westerly wind-driven wave events. Secondly, as previously mentioned, wave refraction due to Square Head causes longshore drift of sediment from the western end of Cullendulla beach to the eastern confluence between Cullendulla Creek and Batemans Bay, forming an ebb-tide delta [17,22]. Finally, due to the aforementioned dredging near Corrigans Beach, most of the fluvial sediment from Clyde River is transported through the deeper channel towards Corrigans Beach, rather than Surfside during occasional flooding events. As a result, sediment inputs to Surfside, and by extent Cullendulla, have been significantly reduced. These three factors may have resulted in a consistent net loss in sediment from Cullendulla Beach, causing the observed erosional trends.

\subsection{Limitations of Field Data}

Though an ECL event was recorded during the measurement period, the analysis of the impacts of the ECL could have benefited from closer pre- and post-storm morphological comparisons. In particular, the investigation could have benefited from an additional measurement a fortnight after the ECL event, in order to investigate whether Cullendulla Beach had recovered from the event.

Additionally, the investigation could have benefited from a more regular measurement interval. However, this was made impossible by extensive road closures due to 2019-2020 New South Wales bushfires.

As dumpy level profiling is a manual process that can only measure onshore beach profiles, the beach profiles do not exactly align with the historic profiles, which are derived from stereo airphoto photogrammetry. Furthermore, exact datum points for the corresponding historic profiles could only be approximated.

\section{Historic Data}

The significance of historical profiles and storm records was limited to identifying recessional and accretional trends due to the long intervals between each profile. Definitive conclusions about the impact of major storm events cannot be made due to the three to five-year gaps between profiles. The historic profiles also vary in the number of data points per year and the method used to record profiles. Later beach profiles measure greater numbers of points using Lidar technology compared to the stereo photogrammetry of earlier profiles.

\section{Conclusions and Future Studies}

This paper combines beach geomorphological data (both long-term/historical and new measurements) with meteorological and oceanographic data to evaluate the impacts of large storm events on three bay and estuary beaches (Cullendulla Beach, Corrigans Beach, and Maloney's Beach) in Batemans Bay, NSW. This investigation sought to explore the impacts of storms on embayed beaches. The results reveal that storms do not generally cause the erosion of embayed beaches, but can exacerbate pre-existing erosional trends.

Field data revealed that only Cullendulla Beach was significantly eroded by easterly storm events. Otherwise, the erosional capacity of storms on embayed beaches is subject to spatial factors, primarily wind and wave directions. Additionally, winter storm seasons may have a greater erosional impact compared to summer seasons due to the reconstructive potential of summer swell waves.

Historic analysis reveals that storms are not the primary threat to Batemans Bay's beach health. Instead, fluvial sediment deprivation due to anthropogenic modifications, such as channel dredging, among other factors, is responsible for the erosive and accretional features in Cullendulla Beach and Corrigans Beach, respectively. In fact, storm and flood events may even help rejuvenate depleted sediment on Cullendulla Beach.

Therefore, our study concludes that these BEBs in Batemans Bay behave differently under different time scales. While the embayed beaches are protected from some storm 
events in the short term, storm impacts may vary with the season due to wind speed and direction changes, and the presence of nearby rivers or creeks and anthropogenic modifications such as dredging and coastline alterations affect their long-term accretion or erosion.

Therefore, the threat posed by coastal storms to embayed beaches within Batemans Bay can be said to be relatively low. This conclusion may apply to other embayed beaches along the east coast, including Jervis Bay and Ulladulla in NSW.

\section{Possible Extensions}

Within Batemans Bay, this investigation could be extended to examine Surfside Beach and Long Beach. Both beaches may undergo more erosion due to their orientation towards open ocean (Figure 1), especially Long Beach, which lacks protection to the east. The orientation of the beaches toward the ocean may also result in a greater vulnerability to southerly wind-driven events. Surfside Beach suffers from a similar lack of fluvial sediment input, while also lacking eastern protective headlands, suggesting that it should experience similar trends to Cullendulla Beach. This investigation should also be applied to other generally protected bays, such as Jervis Bay, which may show similar degrees of vulnerability.

Finally, Batemans Bay is a complex marine system affected by waves, tides, occasional floods, and the flood-tide delta (FTD). Changes in the FTD morphology and associated wave-tide-river dynamics have major impacts on the backing beach systems. To fully understand the dynamic processes of this complex system, a long-term high-resolution field monitoring and wave-current-sediment-morphology coupled numerical modeling program is needed, although it is clearly beyond the scope of this paper to fully address these issues.

Author Contributions: Conceptualization, A.W.; methodology, A.W.; formal analysis, A.W.; investigation, A.W.; resources, A.W. and G.Y.; data curation, A.W.; writing-original draft preparation, A.W.; writing-review and editing, A.W. and X.H.W.; visualization, A.W. and X.H.W.; supervision, X.H.W.; project administration, A.W. All authors have read and agreed to the published version of the manuscript.

Funding: This research received no external funding.

Institutional Review Board Statement: Not applicable.

Informed Consent Statement: Not applicable.

Acknowledgments: This study is based on the Extended Essay project in fulfilment of the requirements for the first author's (A.W.) International Baccalaureate (IB) at the Canberra Grammar School (CGS), Canberra, Australia. We thank the Bureau of Meteorology, the Manly Hydraulics Lab, and the Eurobodalla Shire Council for supplying wave and wind data, as well as reports pertaining to Batemans Bay. A.W. is grateful to Thomas Oliver from UNSW Canberra for beach survey equipment and project advice. A.W. is also grateful to his family for supporting his field trips to Batemans Bay, some of which required drives of up to $8 \mathrm{~h}$ due to road closures as a result of the 2019-2020 NSW bushfires, being his fieldwork aids, and financially supporting his project by paying for data request quotes. Finally, A.W. would like to thank his supervisors from CGS, who helped with the early framework and requirements for the project and acted as advisory guides throughout the writing process. The comments from three anonymous reviewers are constructive and have improved this paper.

Conflicts of Interest: The authors declare no conflict of interest.

\section{References}

1. Kleeman, G.; Rhodes, H. A Geography of Global Interactions; Heinemann: Portsmouth, NH, USA, 2000.

2. Code, B.; Tarasov, A. Sydney Homes Evacuated as King Tide Combines with East Coast Low. ABC News, 2016. Available online: https: / / www.abc.net.au/news/2016-0606/nswhomes-evacuated-as-king-tide-combines-with-east-coast-low /7479736 (accessed on 5 April 2020). 
3. Coates, B.; Hanslow, D.; Lord, D. NSW Coastal Zone Management Manual; Department of Environment and Climate Change: Newcastle, UK, 2007.

4. Pawlukiewicz, M.; Gupta, P.K.; Koelbel, C. Ten Principles for Coastal Development; ULI-the Urban Land Institute: Washington, DC, USA, 2007.

5. Loureiro, C.; Ferreira, Ó.; Cooper, J.A.G. Non-uniformity of storm impacts on three high-energy embayed beaches. In Journal of Coastal Research, Proceedings of the 13th International Coastal Symposium, Durban, Africa, 13 April 2014; Green, A.N., Cooper, J.A.G., Eds.; 2014; pp. 326-331.

6. Fernandez, G.B.; Bulhoes, E.; Rocha, T.B. Impacts of Severe Storm Occurred in April 2010 along Rio de Janeiro Coast, Brazil. Journal of Coastal Research, SI 64. In Proceedings of the 11th International Coastal Symposium, Szczecin, Poland, 9 May 2011; pp. 1850-1854.

7. Harley, M.; Turner, I.; Kinsela, M.; Middleton, J.; Mumford, P.; Splinter, K.; Phillips, M.; Simmons, J.; Hanslow, D.; Short, A. Extreme Coastal Erosion Enhanced by Anomalous Extratropical Storm Wave Direction. Scientific Reports, $2017 ; 7$.

8. Hennecke, W. GIS Modelling of Sea-Level Rise Induced Shoreline Changes Inside Coastal Re-Rntrants Two Examples from Southeastern Australia. Nat. Hazards 2004, 31, 253-276. [CrossRef]

9. Kinsela, M.; Morris, B.; Linklater, M.; Hanslow, D. Second-Pass Assessment of Potential Exposure to Shoreline Change in New South Wales, Australia, Using a Sediment Compartments Framework. J. Mar. Sci. Eng. 2017, 5, 61. [CrossRef]

10. Harley, M.D.; Turner, I.L.; Short, A.D. New insights into embayed beach rotation: The importance of wave exposure and cross-shore processes. J. Geophys. Res. Earth Surf. 2015, 120, 1470-1484. [CrossRef]

11. Vila-Concejo, A.; Gallop, S.; Largier, J. Sandy beaches in estuaries and bays. In Sandy Beach Morphodynamics; Short, D.J.A., Ed.; Elsevier: Amsterdam, The Netherlands, 2020; p. 814. ISBN 9780081029275.

12. Braga, A.K.; Pierri, G.C.S.; Menezes, J.T.; Klein, A.H.E. Shoreline change analysis near itapocu river inlet, (1978 to 2002$)$. J. Coast. Res. 2006, 39, 298-300.

13. de Oliveira, G.G.; Gastão, F.G.C.; Pinheiro, L.S. Evolution of the coast line and associated impacts in coastal Ceará State, Northeast, Brazil. Rev. Bras. De Geogr. Física 2018, 11, 1215-1225.

14. Burston, J. Stochastic Model of Extreme Coastal Water Levels. Ph.D. Thesis, University of Sydney, New South Wales, Australia, 2008.

15. Quickstats.censusdata.abs.gov.au. 2016 Census QuickStats: Batemans Bay. 2016. Available online: https://quickstats.censusdata. abs.gov.au/census_services/getproduct/census/2016/quickstat/UCL113002 (accessed on 24 December 2019).

16. Manly Hydraulics Lab. NSW Ocean And River Entrance Tidal Levels Annual Summary 2016-2017; NSW Office of Environment and Heritage: Manly Vale, Australia, 2017.

17. Water Research Laboratory. Eurobodalla Coastal Hazard Assessment; University of New South Wales: Manly Vale, Australia, 2017.

18. Switzer, A.; Sloss, C.; Jones, B.; Bristow, C. Geomorphic evidence for mid-late Holocene higher sea level from southeastern Australia. Quat. Int. 2010, 221, 13-22. [CrossRef]

19. SMEC Australia. Eurobodalla Shire Coastal Hazards Scoping Study; SMEC Australia: Sydney, Australia, 2010.

20. Del Río, L.; Gracia, F. Error determination in the photogrammetric assessment of shoreline changes. Nat. Hazards 2012, 65, 2385-2397. [CrossRef]

21. Mortlock, T.; Somerville, P. February 2020 East Coast Low: Sydney Impacts Risk Frontiers. RISK FRONTIERS, 2020. Available online: https: / / riskfrontiers.com/february-2020east-coast-low-sydney-impacts / (accessed on 4 April 2020).

22. Patterson, Britton and Partners [PBP]. Land at Cullendulla Creek, Surfside Flooding, Beach Stability and Drainage Issues, Coastal Engineers Report. Report Prepared for Developer. 1992.

23. Cooper, J.; Jackson, D.; Navas, F.; McKenna, J.; Malvarez, G. Identifying storm impacts on an embayed, high-energy coastline: Examples from western Ireland. Mar. Geol. 2004, 210, 261-280. [CrossRef]

24. BMT WBM. Wharf Road Coastal Hazard Assessment and Hazard Management Plan. Report prepared for Eurobodalla Shire Council. 2019.

25. SLS Beachsafe. Corrigans Beach in Catalina Eurobodalla NSW. 2020. Available online: https://beachsafe.org.au/beach/nsw/ eurobodalla/catalina/corrigans (accessed on 5 April 2020).

26. NSW National Parks and Wildlife Service. Cullendulla Creek Nature Reserve Plan of Management. NSW: NSW National Parks and Wildlife Servic, 2004. Available online: https://www.environment.nsw.gov.au/-/media/OEH/Corporate-Site/Documents/ Parks-reservesand-protected-areas / Parks-plans-of-management/cullendulla-creek-nature-reserve-plan-ofmanagement-0401 33.pdf (accessed on 4 April 2020). 